\title{
Correlation between temperature and the timing of arrival of geese in South Korea
}

\author{
Min-kyung Kim ${ }^{1,3}$, Sang-im Lee ${ }^{2}$, Piotr G. Jablonski, ${ }^{3,4}$ and Sang-Don Lee ${ }^{1 *}$
}

\begin{abstract}
The impact of climate change on animals has been globally documented. Especially, migration of birds has been extensively monitored as migratory birds are susceptible to any changes occurring both on breeding grounds and on wintering grounds. However, in contrast to spring migration, the patterns and the factors for autumn migration have not been well documented. In this study, we investigated the relationship with climate condition and the first arrival dates (FADs) of bean geese (Anser fabalis) and white-fronted geese (A. albifrons), the representative group of wintering birds in South Korea, using the data collected by Korean Meteorological Association during 1995-2016. Average temperature of September in wintering grounds has increased, and the FADs of the geese have advanced over the 22 years. Even when the influence of autumn temperature was statistically controlled for, the FADs of the geese have significantly advanced. This suggests that warming has hastened the completion of breeding, which speeded up the arrival of the geese at the wintering grounds. In order to assess the effect of climate condition on the arrival of the wintering migratory birds such as the geese in more detail, extensive data collection over many sampling sites and with long-term monitoring is needed.
\end{abstract}

Keywords: Temperature, First arrival date, Geese, Autumn migration

\section{Introduction}

Global climate change is happening all over the world. The climate change causes seasonal changes in the biology of many species on the Earth. It is well known that climate change has a great influence on habitat location and size, breeding success rate, species richness, etc. (Penuelas and Filella 2001; Walther et al. 2002; Root et al. 2003; Lemoine et al. 2007). It has also been reported in many studies over the past several decades that climate change also affects the timing of seasonal activities such as the breeding of animals and flowering of plants (e.g., Hughes 2000; Root et al. 2003; Visser and Both 2005). Phenology is defined as the study of the timing of recurrent biological phenomena, the causes of time changes related to biotic and abiotic factors, and the interrelationships between species (Leith 1974). In recent years, phenological studies recognize climate change through the analysis of correlations between biological seasonal responses and climate factors (Sparks et al.

\footnotetext{
* Correspondence: Isd@ewha.ac.kr

${ }^{1}$ Department of Environmental Science and Engineering, Ewha Womans

University, Seoul 03760, South Korea

Full list of author information is available at the end of the article
}

2000) and identify that climate change affects the seasonal responses of organisms (e.g., Visser et al. 2009).

Globally, the responses of organisms to climate change have been studied mostly on the organisms that breed in spring. This is presumably due to the assumption that they are more vulnerable to any impact of climate change. Because of the global warming, the organisms that breed in spring would directly experience the change in the breeding environment, which induces the organisms to shift the timing of breeding activities. Therefore, there have recently been many phenological studies like the time of leaf unfolding or flowering (Badeck et al. 2004), timing of the first activity in spring in animals (Prodon et al. 2017), and timing of migration toward breeding grounds in migratory birds (reviewed in Gordo 2007; Lehikoinen and Sparks 2010). In particular, migration of migratory birds is closely related to the seasonal changes in climate and availability of food (Carey 2009). The responses of migratory populations has been studied in various ways using arrival date data collected for decades centered on Europe and North America (Sparks 1999; Tryjanowski and Sparks 2001; Butler 2003; Cotton 2003; Murphy-Klassen et al. 2005). 
However, climate change in temperate regions can be important to organisms not only at the time of increasing temperature, i.e. in the spring, but also at the time when the temperature decreases, i.e., in the autumn. In this regard, the correlation between climate change and the phenological response of long distance migratory birds moving from breeding to wintering grounds in autumn should be examined. However, despite the significance (Cotton 2003; Robinson et al. 2008), there are not many studies that concern the timing of autumn migration of birds (Kobori et al. 2012). There are two opposing predictions for the migration time to wintering areas of migratory birds with regard to warming. First, as the global warming progresses, the winter will come later, and the migration time to the wintering area will be delayed accordingly. On the contrary, as the global warming progresses, the spring will come earlier, and the migration time to the wintering area will be accelerated (Sokolov et al. 1999). Which of these hypothetical mechanisms explain the fall migration better remains to be explored?

Phenological changes of animals and plants in response to climate change are also seen in the species living on the Korean peninsula. However, most studies on the seasonal changes in the Korean peninsula have been conducted mainly on plants (Lee et al. 2009; Ibanez et al. 2010). There are not many studies on the biological seasonal phenomena of animals, and those studies that concerned seasonal phenomena dealt with the species initiate activities in spring such as butterflies, frogs, and the birds that migrate in spring (Kwon et al. 2010; Lee et al. 2011; Yoo and Jang 2012). In particular, there is no phenological study on the fall arrival time of migratory birds on the Korean peninsula.

Geese (Anser spp.) are members of the duck family (Anatidae) and are the representative winter migratory birds in Korea. Tens of thousands of individuals visit Korea every year. Bean geese (A. fabalis) and white-fronted geese (A. albifrons) are the most dominant geese that overwinter in Korea (Park and Won 1993). In particular, bean geese are designated as class 2 of the endangered species (Rho et al. 2010) and Climate-sensitive Biological Indicator Species by Ministry of the Environment of Korea (Ministry of the Environment, 2010). In this study, we aimed to unravel the correlation between the climate change in the Korean peninsula and the seasonal responses of the arrival of the geese using the arrival date data of the geese collected from Korea Meteorological Administration (KMA).

\section{Materials and methods}

Geese are distributed in rice paddies, river, and reservoir across the Korean peninsula and winter in Cheorwon, Han River Estuary, Seosan, Junnam Reservoir, Nakdong
River Estuary, and Haenam etc. (Won and Kim 2012; Kim et al. 2016). We analyzed the first arrival date (FAD) data of the geese collected from Korea Meteorological Administration (available from the website; www.kma.go.kr). The Korea Meteorological Administration (KMA) conducts seasonal observations of the state of flora and fauna representing the season to document the effect of climate change on the living organisms and has collected 20 biota seasonal observational data from 74 meteorological stations since 1921 (Primack et al. 2009). Among these data, geese are the only winter visitors and have started to be observed at three sites since 1994. Since the different geese species readily form a mixed-species flock and they have tendencies to migrate together (Authors' observation), KMA records do not distinguish the species identity. Thus, in this paper, we use the term "geese" as a collective term.

In this study, we used the data from 24 regions with more than 5 years data. A total of 223 first arrival data recorded for 22 years from 1995 to 2016 were analyzed (Table 1, Fig. 1). As the climate data, we used the average

Table 1 Locations where the geese FADs were collected in this study

\begin{tabular}{|c|c|c|c|}
\hline $\begin{array}{l}\text { Study site } \\
\text { number }\end{array}$ & Meteorological stations & Latitude & Longitude \\
\hline 1 & Sokcho & 38.251 & 128.565 \\
\hline 2 & Cheorwon & 38.148 & 127.304 \\
\hline 3 & Dongducheon & 37.902 & 127.061 \\
\hline 4 & Paju & 37.886 & 126.766 \\
\hline 5 & Chuncheon & 37.903 & 127.736 \\
\hline 6 & Baekryongdo & 37.966 & 124.630 \\
\hline 7 & North Gangneung & 37.805 & 128.855 \\
\hline 8 & Gangneung & 37.751 & 128.891 \\
\hline 9 & Incheon & 37.478 & 126.624 \\
\hline 10 & Yeongwol & 37.181 & 128.457 \\
\hline 11 & Seosan & 36.777 & 126.494 \\
\hline 12 & Uljin & 36.992 & 129.413 \\
\hline 13 & Pohang & 36.033 & 129.380 \\
\hline 14 & Changwon & 35.170 & 128.573 \\
\hline 15 & Busan & 35.105 & 129.032 \\
\hline 16 & Jinju & 35.164 & 128.040 \\
\hline 17 & Yangpyeong & 37.489 & 127.494 \\
\hline 18 & Jecheon & 37.159 & 128.194 \\
\hline 19 & Boeun & 36.488 & 127.734 \\
\hline 20 & Boryeong & 36.327 & 126.557 \\
\hline 21 & Buyeo & 36.272 & 126.921 \\
\hline 22 & Youngdeok & 36.533 & 129.409 \\
\hline 23 & Milyang & 35.491 & 128.744 \\
\hline 24 & Sancheong & 35.413 & 127.879 \\
\hline
\end{tabular}




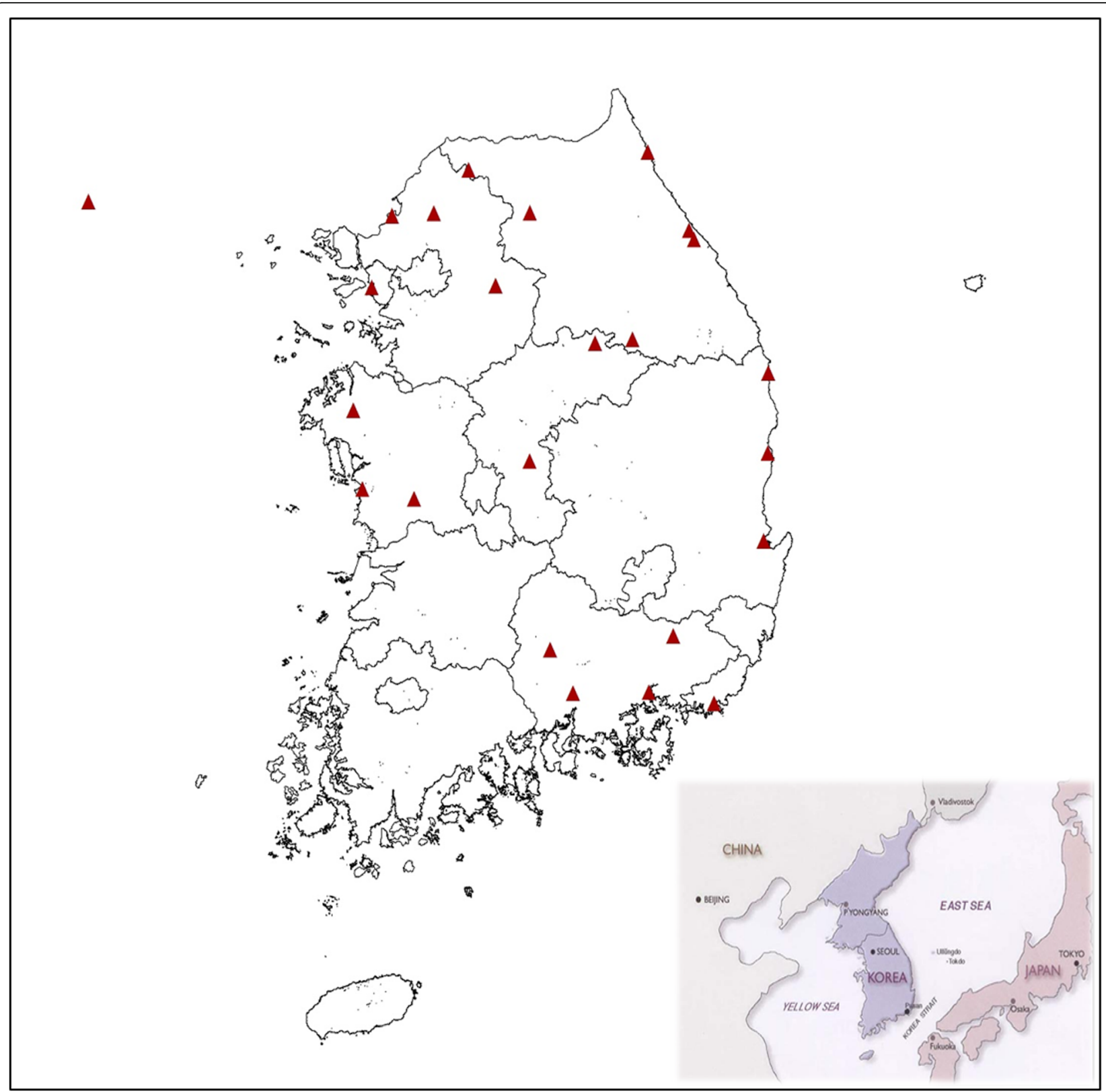

Fig. 1 The location of meteorological stations (

) whose data were used in this study. See Table 1 for the GPS information

temperature of September at each site retrieved from the Korea Meteorological Administration. This is the time when the geese populations began to arrive on the Korean peninsula.

As both FAD data and temperature data followed normal distribution (FAD Shapiro-Wilk $=0.989, \mathrm{df}=223, P$ $=0.089$; temp. Shapiro-Wilk $=0.990, \mathrm{df}=223, P=0.139$ ), we conducted Pearson correlation and regression analyses between the average temperature of September and FAD at each site. In order to examine the tendency of FAD across the years, we also conducted partial correlation analysis using either average temperature of
September or year as a covariate. IBM SPSS Statistics 23.0 was used for statistical analyses.

\section{Results}

The FAD of geese has been recorded in the range from 254 days in Cheorwon in 1999 to 353 days in Chuncheon in 2007 due to regional and yearly variation (mean \pm SD, $303.6 \pm 20.8$ days). From 1995 to 2016 , the FAD of geese significantly advanced (Fig. 2a; $r=-0.769, n=22, P=$ $0.000)$. The average temperature of September ranged from $16.2^{\circ} \mathrm{C}$ in 1995 of Jecheon to $24.3^{\circ} \mathrm{C}$ in 1998 and 1999 of Changwon. Overall, the average temperature of 


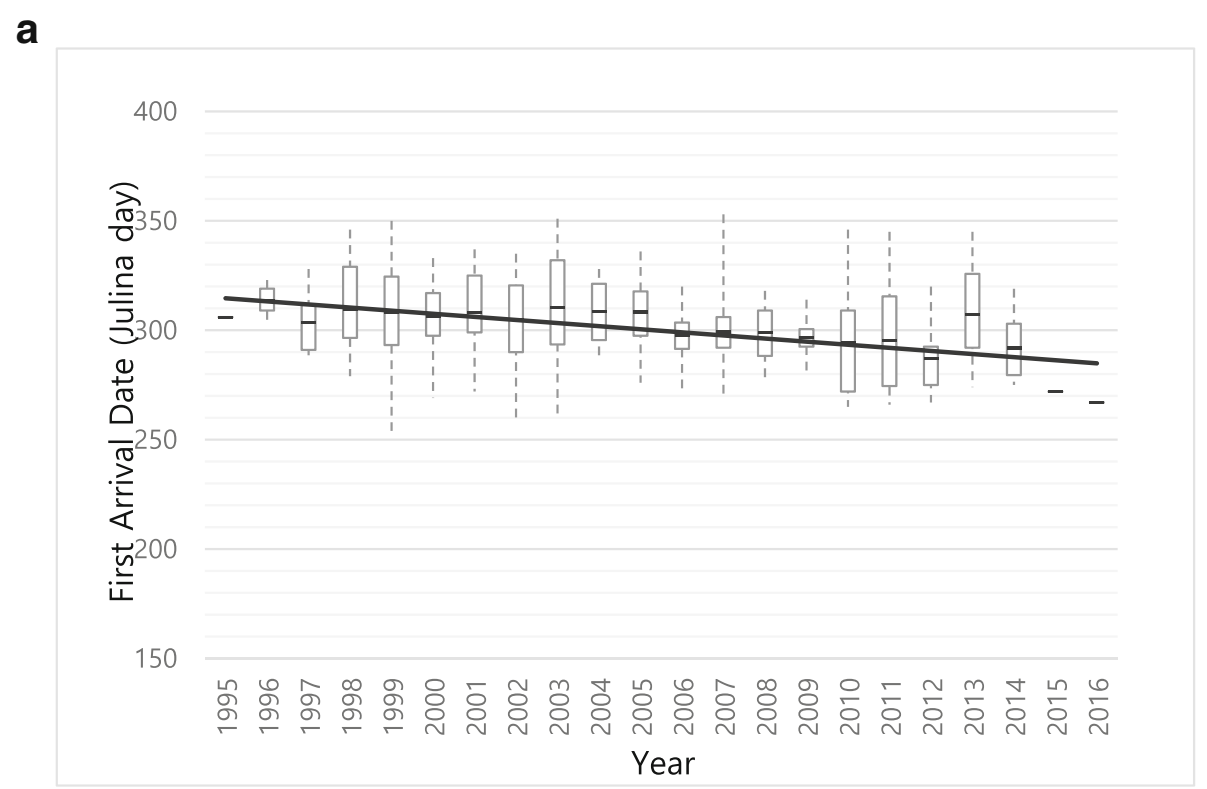

b

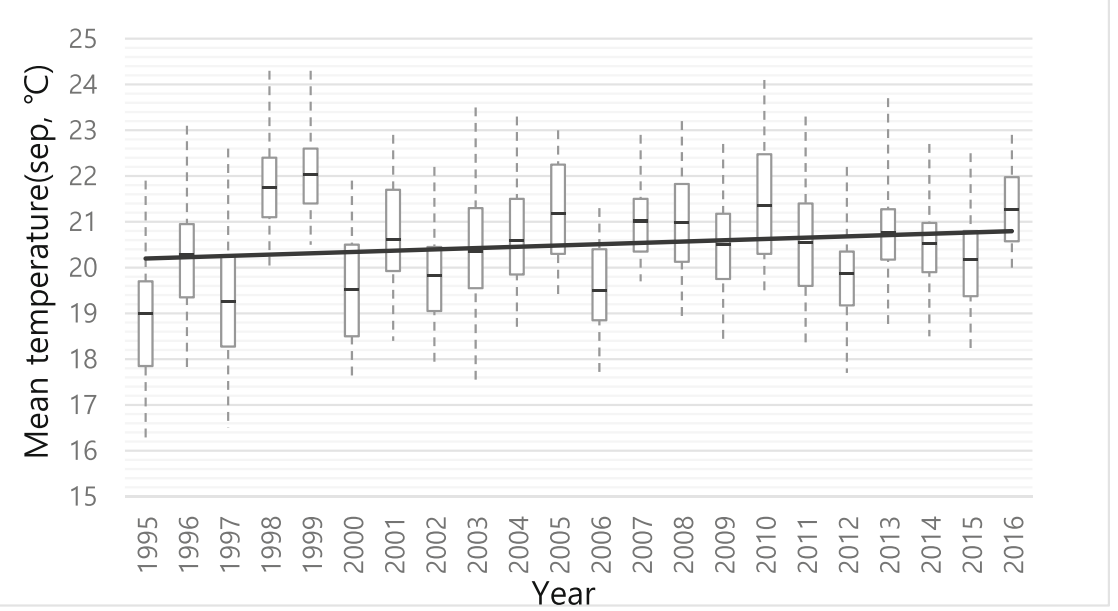

Fig. 2 Trends of the (a) average first arrival date (FAD) of the geese $\left(y=-1.417 x+316.03, R^{2}=0.592\right)$, and $(\mathbf{b})$ average September temperature recorded in 24 study sites in South Korea between 1995 and $2016\left(y=0.028 x+20.171, R^{2}=0.054\right)$. The whiskers of box plot represent the minimum and maximum of FAD

September tended to slowly increase over the course of the years, although statistically not significant (Fig. $2 \mathrm{~b} ; r=$ $0.233, n=22, P=0.298$ ).

The average temperature of September at each site and FAD showed a positive relationship (Fig. 3, $r=$ $0.170, n=223, P=0.011)$. However, this relationship itself does not tell us whether the FAD of the geese is indeed decreasing across the years or it is simply the response of the warming in the localities. Thus, we conducted a partial correlation analysis using the average temperature of September as a covariate. As the results, we found that FAD of the geese significantly advanced across the years even after the effect of the average temperature of September was controlled for (partial correlation $\quad r=-0.269, \quad \mathrm{df}=220, \quad P<0.001) . \quad$ This tendency also can be seen by the negative relationship between the year and the FAD divided by the average temperature of September (Fig. 4, $r=0.654, n=22, P=$ 0.000 ). On the other hand, when the effect of the year was excluded, there was a positive correlation between the average temperature and the date of arrival in September (partial correlation $r=0.173, \mathrm{df}=220, P=0.010$ ), which suggests that the geese indeed arrived later in warmer years.

\section{Discussion}

This study was conducted to investigate the phenological response of autumn migrations of the geese to South Korea from Siberia. The average temperature of September tended to increase over the years we considered. 


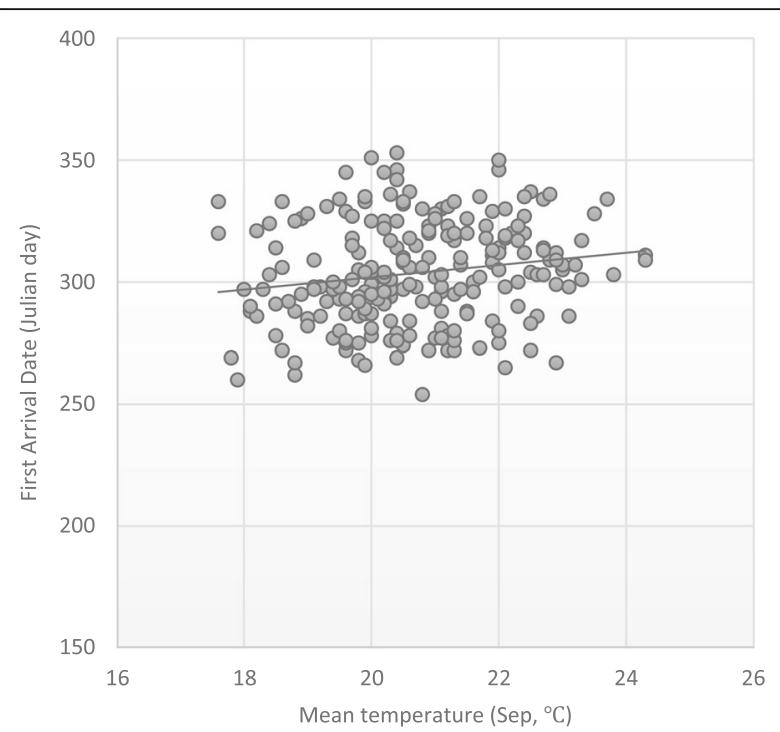

Fig. 3 The relationship between first arrival date of the geese species and average September temperature $\left(y=2.519 x+251.5, R^{2}=0.029\right)$

Thus, it can be said that the Korean peninsula experiences the effect of warming.

We found that the arrival of the geese for wintering in Korean peninsula advanced in recent years and this remained significant even when the effect of warming was excluded. In case of spring migration, there are many studies that show the advancing of the birds' arrival due to global warming (Butler 2003; Ledneva et al. 2004; Murphy-Klassen et al. 2005). However, corresponding pattern for autumn migration is not consistent (Mills 2005). Autumn migration depends on species specificity and breeding conditions (Gordo 2007). When the temperature is high in the autumn, short-distance migrants stay long in warm breeding areas and arrive late to wintering grounds (Gordo 2007). On the other hand, long-distance migrants that breed once breed quickly and arrive early at the wintering grounds, but the multiple-brooded species depart the breeding area late and arrive late at the wintering grounds (Gordo 2007). Geese are long-distance migratory birds, and they are generally known to breed once (Fox 2005). Therefore, the pattern we found, that the geese arrival dates advance with years, seems consistent with the hypothesis that the geese arrive at Korean peninsula earlier across the years because the completion of their breeding in $\mathrm{Si}$ beria became earlier due to the effect of global warming.

For spring migration, many studies found a negative correlation with the April temperature and the arrival at the breeding area (Sparks et al. 2002). For the autumn migration of the geese, we found a positive correlation between the September temperature and the arrival of the geese; the warmer the autumn, the later the arrival of the geese. The reason for this tendency is unclear. In order to understand this, it is necessary to investigate the departure date and the duration of migration from breeding area to wintering area and what factors are involved. It is also necessary to investigate the condition of stopover routes (O'Neal et al. 2012). In addition, the FADs of the geese will need to be closely studied in relation to other climate factors such as temperatures of other months and/or precipitation that may represent the feeding environment of the geese during the winter. Even though we could not explore these possibilities, our results are still meaningful considering the fact that there are not many domestic and overseas studies for the responses of wintering birds. We believe more data is needed in order to understand the effect of climate change on the migratory ecology of the geese. In this sense, it is a pity that the survey of geese that have been

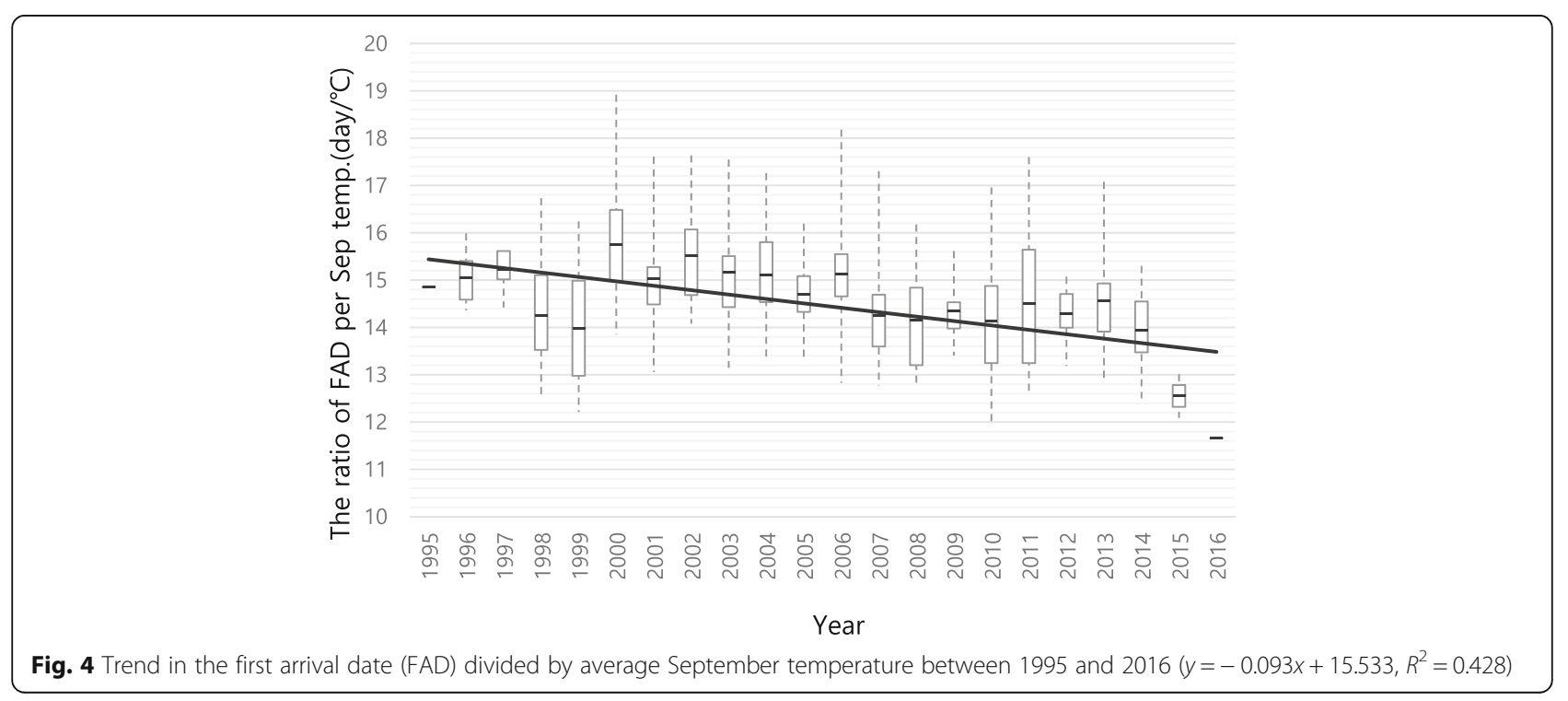


used as a seasonal indicator for autumn has been discontinued since 2017 and is no longer carried out by Korea Meteorological Administration any more. In order to examine the responses of living organisms to climate change, continuous and long-term monitoring should be guaranteed. We strongly urge that more systematic effort should be made to record seasonal changes in more diverse species, including the geese, across the country. These would heighten the status of Korea in a global network for migratory bird research, in the times when the importance of international collaboration for data collection for breeding, stopover, and wintering ecology is more augmented than ever.

\section{Conclusions}

The FADs of geese in South Korea varies from region to region, ranging from 254 days in Cheorwon in 1999 to 353 days in Chuncheon in 2007. According to the results of this study, the arrival of the geese for wintering in Korean peninsula advanced in recent years, and this remained significant even when the small effect of warming was excluded. As long-term data are essential for broad understanding the factors that affect migratory birds, continuous and long-term monitoring should be guaranteed.

\section{Abbreviations}

FADs: First arrival dates; KMA: Korea Meteorological Administration

\section{Acknowledgements}

We sincerely appreciate the efforts of the Ministry of Environment, the Korea Meteorological Administration, and many researchers who contributed to the data collection.

\section{Funding}

Funding was provided from NRF grants 2017R1D1A1B03029300 and 2018R1A6A3A01012729.

\section{Availability of data and materials}

The datasets during and/or analyzed during the current study are available from the corresponding author on reasonable request.

\section{Authors' contributions}

All authors contributed to shaping of the paper. All authors read and approved the final manuscript.

\section{Ethics approval and consent to participate}

Not applicable

\section{Consent for publication}

Not applicable

\section{Competing interests}

The authors declare that they have no competing interests.

\section{Publisher's Note}

Springer Nature remains neutral with regard to jurisdictional claims in published maps and institutional affiliations.

\section{Author details}

'Department of Environmental Science and Engineering, Ewha Womans University, Seoul 03760, South Korea. ${ }^{2}$ School of Undergraduate Studies, Daegu-Gyeongbuk Institute of Science and Technology, Daegu 42988, South
Korea. ${ }^{3}$ School of Biological Sciences, Seoul National University, Seoul 08826, South Korea. ${ }^{4}$ Museum and Institute of Zoology PAS, Wilcza 64, 00-679

Warsaw, Poland.

Received: 4 October 2018 Accepted: 19 November 2018

Published online: 18 December 2018

\section{References}

Badeck FW, Bondeau A, Böttcher K, Doktor D, Lucht W, Schaber J, Sitch S. Responses of spring phenology to climate change. New Phytologist Trust. 2004:162:295-309.

Butler CJ. The disproportionate effect of global warming on the arrival dates of short-distance migratory birds in North America. Ibis. 2003;145:484-95.

Carey C. The impacts of climate change on the annual cycles of birds. Philosophical Transactions of the Royal Society B: Biological Sciences. 2009; 364:3321-30

Cotton PA. Avian migration phenology and global climate change. Proc Natl Acad Sci U S A. 2003:100:12219-22.

Fox AD. Lesser white-fronted goose Anser erythropus. In: Kear J, editor. 2005. Ducks, Geese and Swans, vol. Volume 1. Oxford: Oxford University Press; 2005. p. 286-9.

Gordo $\mathrm{O}$. Why are bird migration dates shifting? A review of weather and climate effects on avian migratory phenology. Clim Res. 2007;35:37-58.

Hughes L. Biological consequences of global warming: is the signal already apparent? Trends in Ecology and Evolution. 2000;15:56-61.

Ibanez I, Primack RB, Miller-Rushing AJ, Ellwood E, Hiquchi H, Lee SD, Kobori H, Silander JA. Forecasting phenology under global warming. Philosophical Transactions of the Royal Society B - Biological Sciences. 2010;365:3247-60.

Kim MK, Lee S, Lee SD. Habitat use and its implications for the conservation strategies for the overwintering populations of the Bean goose (Anser fabalis) and the white-fronted goose (A. albifrons) in South Korea. Ornithol Sci. 2016; 15:141-9.

Kobori H, Kamamoto T, Npmura H, Oka K, Primack R. The effects of climate change on the phenology of winter birds in Yokohama, Japan. Ecol Res. 2012;27:173-80.

Kwon T-S, Kim S-S, Chun JH, Byun B-K, Lim J-H, Shin JH. Changes in butterfly abundance in response to global warming and reforestation. Environ Entomol. 2010;39:37-345.

Ledneva A, Miller-Rushing AJ, Primack RB, Imbres C. Climate change as reflected in a naturalist's diary, Middleborough, Massachusetts. Wilson Bulletin. 2004; 116:224-31.

Lee K, Kwon WT, Lee SH. A study on plant phenological trends in South Korea. Journal of the association of Korean geographers. 2009;15:337-50 (in Korean).

Lee SD, Ellwood ER, Park SY, Primack RB. Late-arriving barn swallows linked to population declines. Biol Conserv. 2011;144:2182-7.

Lehikoinen E, Sparks TH. Changes in migration. In: Møller AP, Fiedler W, Berthold P, editors. Effects of climate change on birds. Oxford: Oxford University Press; 2010. p. 89-112.

Leith H. Purposes of a phenology book. In: Leith H, editor. Phenology and seasonality modeling, vol. 8. New York: Springer-Verlag; 1974. p. 3-19.

Lemoine N, Schaefer H-C, Bohning-Gaese K. Species richness of migratory birds is influenced by global climate change. Glob Ecol Biogeogr. 2007;16:55-64.

Mills A. Changes in the timing of spring and autumn migration in North American migrant passerines during a period of global warming. Ibis. 2005: 147:259-69.

Ministry of the Environment. (2010) http://www.nibr.go.kr.

Murphy-Klassen HM, Underwood TJ, Sealy SG, Ashleigh AC. Long-term trends in spring arrival dates of migrant birds at Delta Marsh, Manitoba, in relation to climate change. Auk. 2005;122:1130-48.

O'Neal BJ, Stafford JD, Larkin RP. Stopover duration of fall-migrating dabbling ducks. J Wildl Manag. 2012;76:285-93.

Park JY, Won PO. Wintering ecology of Bean goose (Anser fabalis) and Whitefronted goose (Anser albifrons) in Junam reservoirs. Korea Bulletin of Korea Institute of Ornithology. 1993;4:1-24 (in Korean).

Penuelas J, Filella I. Responses to a warming world. Science. 2001:294:793-4.

Primack RB, Ibanez I, Higuchi H, Lee SD, Miller-Rushing AJ, Wilson AM, Silander JA. Spatial and interspecific variability in phenological responses to warming temperatures. Biological Conservation. 2009;142:2569-77.

Prodon R, Geniez P. Cheylan M, Devers F, Chuine I, Besnard A. A reversal of the shift towards earlier spring phenology in several Mediterranean reptiles and 
amphibians during the 1998-2013 warming slowdown. Glob Chang Biol. 2017:23(12):5481-91.

Rho PH, Yoon JH, Choi JK, Lee SW, Sou HJ. Habitat evaluation strategy for legally protected wildbirds in Korea. Korean: Korea Environ Inst; 2010. ROK

Robinson RA, Crick HQP, Learmonth JA, Maclean IMD, Thomas CD, Bairlein F, Forchhammer MC, Francis CM, Gill JA, Godley BJ, Harwood J, Hays GC, Huntley B, Hutson AM, Pierce GJ, Rehfisch MM, Sims DW, Santos MB, Sparks $\mathrm{TH}$, Stroud DA, Visser ME. Travelling through a warming world: climate change and migratory species. Endanger Species Res. 2008;7:87-99.

Root TL, Price JT, Hall KR, Schneider SH, Rosenzweig C, Pounds JA. Fingerprints of global warming on wild animals and plants. Nature. 2003:421:57-60.

Sokolov LV, Markovets MY, Morozov YG. Long-term dynamics of the mean date of autumn migration in passerines on the Courish Spit of the Baltic Sea. Avian Ecology and Behaviour. 1999;2:1-18.

Sparks TH, Crick HQP, Elkins N, Moss R, Moss S, Mylne K. Birds, weather and climate. Weather. 2002:57:399-410.

Sparks TH. Phenology and the changing pattern of bird migration in Britain. Int J Biometeorol. 1999;42:134-8.

Sparks TH, Jeffree EP, Jeffree CE. An examination of the relationship between flowering times and temperature at the national scale using long-term phenological records from the UK. Int J Biometeorol. 2000;44:82-7.

Tryjanowski P, Sparks TH. Is the detection of the first arrival date of migrating birds influenced by population size? A case study of the red-backed shrike Lanius collurio. Int J Biometeorol. 2001;45:217-9.

Visser ME, Both C. Shifts in phenology due to global climate change: the need for a yardstick. Proceedings of the Royal Society, Series B. 2005;272:2561-9.

Visser ME, Perdeck AC, van Balen JH, Both C. Climate change leads to decreasing bird migration distances. Glob Chang Biol. 2009;15:1859-65.

Walther GR, Eric P, Peter C, Annette M, Camille P, Trevor JCB, Jean-Marc F, Ove HG, Franz B. Ecological responses to recent climate change. Nature. 2002;416:389-95. Won B, Kim H. The birds of Korean Peninsula. Seoul: Academy Book; 2012.

Yoo E, Jang Y. Abiotic effects on calling phenology of three frog species in Korea. Animal Cells and Systems. 2012;16:260-7.

Ready to submit your research? Choose BMC and benefit from:

- fast, convenient online submission

- thorough peer review by experienced researchers in your field

- rapid publication on acceptance

- support for research data, including large and complex data types

- gold Open Access which fosters wider collaboration and increased citations

- maximum visibility for your research: over $100 \mathrm{M}$ website views per year

At $\mathrm{BMC}$, research is always in progress.

Learn more biomedcentral.com/submissions 